\title{
Transcriptional regulatory network during development in the olfactory epithelium
}

\author{
SeungYeong Im E Cheil Moon * \\ Department of Brain \& Cognitive Sciences, Graduate School, Daegu Gyeungbuk Institute of Science and Technology, Daegu 42988, Korea
}

\begin{abstract}
Regeneration, a process of reconstitution of the entire tissue, occurs throughout life in the olfactory epithelium (OE). Regeneration of OE consists of several stages: proliferation of progenitors, cell fate determination between neuronal and non-neuronal lineages, their differentiation and maturation. How the differentiated cell types that comprise the $O E$ are regenerated, is one of the central questions in olfactory developmental neurobiology. The past decade has witnessed considerable progress regarding the regulation of transcription factors (TFs) involved in the remarkable regenerative potential of $\mathrm{OE}$. Here, we review current state of knowledge of the transcriptional regulatory networks that are powerful modulators of the acquisition and maintenance of developmental stages during regeneration in the $\mathrm{OE}$. Advance in our understanding of regeneration will not only shed light on the basic principles of adult plasticity of cell identity, but may also lead to new approaches for using stem cells and reprogramming after injury or degenerative neurological diseases. [BMB Reports 2015; 48(11): 599-608]
\end{abstract}

\section{INTRODUCTION}

Olfactory epithelium (OE) has representative characteristics of adult neurogenesis and regeneration. To capture the odor required for smell, olfactory receptor neurons (ORNs) are constantly exposed to the environment, including pathogens or other toxic substances, and thereby they are often confronted by degeneration. Therefore, ORNs have a shorter average life-span than that of other neurons. If the degenerated ORNs were not replenished, it would result in a total loss of the sense of smell. As chance would have it, ORNs and other cells in the OE are constantly renewed and replaced over their lifetime (1-4).

*Corresponding author. Tel: +82-53-785-6110; Fax: +82-53-7856109; E-mail: cmoon@dgist.ac.kr

http://dx.doi.org/10.5483/BMBRep.2015.48.11.177

Received 20 August 2015

Keywords: Neurogenesis, Olfactory epithelium, Regeneration, Stem cell, Transcription factor
The capacity of regeneration in the OE has been studied from experimental research in animals (5). Since the morphological reconstitution and functional restoration of OE after injury is relative simple, and the experimental in vivo studies are easy to apply, it offers a unique model system to study adult neurogenesis and regeneration (6-8). Adult neurogenesis occurs in two other areas in the central nervous system (CNS) beside OE: the subgranular zone (SGZ) which supplies new granule cells to the dentate gyrus of the hippocampus, and the subventricular zone (SVZ) which supplies new interneurons to the olfactory bulb (9-11). The OE is an area of particular interest as neurogenesis in the OE rarely exhibits tumor formation, although it follows a process similar to that of SGZ and SVZ in the CNS, presumably reflecting that tight regulation mechanisms might exist (12).

Over the past decade, efforts have been directed to identify the transcription factor (TFs) networks during adult neurogenesis and regeneration in the OE. Although there are a huge number of transcription factors (TFs) that are expressed in the $\mathrm{OE}$, several studies have identified only a few TFs have expression profiles in cell proliferation, shifts in cell fate determination, and differentiation during regeneration. Once the regeneration process has started, the expression of TFs generally shares the pattern of embryonic and postnatal development (13-15). The progenitor cells undergo the same sequence during embryonic development, first actively proliferating, followed by the expression of Mash1, Neurog1, and NeuroD respectively, as they add new ORNs. This suggests that spatial and temporal expression of various TFs determines a cell's 'identity'; this fate selection is highly regulated within the network during regeneration of OE. Indeed, it has been proved for the first time that neurons have the capacity to reprogram their identity using nucleus of ORNs $(16,17)$. Hence, the demonstration of transcriptional regulatory network during regeneration in the OE provide new approaches in using stem cells to repair the adult CNS and sensory systems after injury or degeneration, and the reprogramming which originates from plasticity of the olfactory cell identity $(18,19)$.

This review describes the recent knowledge acquired about the transcriptional regulatory networks responsible for the proliferation, fate determination and differentiation of cells in the OE during adult neurogenesis and regeneration. 


\section{Functional and structural features in the $\mathrm{OE}$}

The olfactory epithelium (OE) is a pseudostratified columnar neuroepithelium present on the nasal septum, and on a series of turbinates in the nasal cavity (Fig. 1A). Most studies about adult neurogenesis or regeneration of the OE have focused on the main olfactory epithelium (MOE) rather than the additional olfactory region such as the vomeronasal organ. There are three major layers in the OE: apical, intermediate, and basal layers. Supporting cells, immature and mature olfactory receptor neurons (ORNs), and horizontal and globose basal cells (HBCs and GBCs), reside in each layer respectively (Fig. 1B). Individual cell types can be identified based on a variety of physiologies (morphology, immune-reactivity and the location within the epithelium), in addition to the inference of their functions (20-23).

ORNs are bipolar, having a single dendrite that extends to the apical surface of the OE; the dendrite has a terminal knob covered with cilia. Upon odorant stimulation, the olfactory receptors in the cilia conduct initial events of olfactory signal transduction, and this signal is transmitted along the axons through the lamina cribosa to the olfactory bulb (24-26). ORNs are renewed throughout life at a regular rate, owing to naturally occurring regeneration (27-30). As they mature, ORNs shift from bottom to apical in the intermediate layers of the $\mathrm{OE}$, reflecting neuronal age by position, with the expression of NCAM, NST and OMP (olfactory marker protein) (31-33).

Stretching from the epithelial surface to the basal lamina, supporting cells surround the ORNs, possessing glial functions in the $\mathrm{OE}(25,34,35)$. They structurally support and electrically isolate the ORNs $(24,36)$. They also have neuroprotective functions through the expression of cytochrome P450 isoform (37), as well as glutathione S-transferases (GSTs) (38) which are responsible for detoxification (39-41). They express several markers including SUS4, REEP6, Ezrin, K18 and Steel. Under normal conditions, the postnatal proliferation of supporting cells occurs very slowly, relative only to growth in the surface area of the $\mathrm{OE}$; however, they comparatively appear more rapidly compared to the ORNs, after severe injury (42, 43).

Basal cells have been divided into two phenotypically distinct categories, the GBCs and $\mathrm{HBCs}$, which are evident in the basal region. GBCs are round in shape and express GBC-1, GBC-3, and GBC-5 as markers $(44,45)$. In normal conditions, they are mitotically active, dividing once per day, with the expression of proneural genes. Some of them are currently considered to be neuronal progenitor cells. HBCs are flat in shape and make direct contact with the basal lamina above the underlying lamina propria. ICAM1 (CD54) and keratin-K5 are representative markers. HBCs serve as reserve pools of longlived progenitors since they are relatively quiescent, dividing once every 60 days under normal regeneration of ORNs, but proliferate more actively during injury-induced regeneration $(3,46-49)$. Thus, the basal cells continuously generate ORNs and other types of cells throughout life as well as after damage of the OE $(15,50)$. Since both basal cells have the capacity as progenitors, their relationship remains elusive as to whether HBCs give rise to GBCs, or vice versa. Recently, it was established that GBCs committed to the ORN lineages descended from keratin K5-expressing HBCs (48). This study puts forward evidence to support the hypothesis that the HBCs are the multipotent progenitors that give rise to all cell types in the $\mathrm{OE}$, including GBCs, in the controversy surrounding 'the' real olfactory stem cell. Detailed roles and mechanisms of basal cells in the $\mathrm{OE}$ contributing to the continuous production of new ORNs, and other cells of the $\mathrm{OE}$, will be described later in the review.
(A)

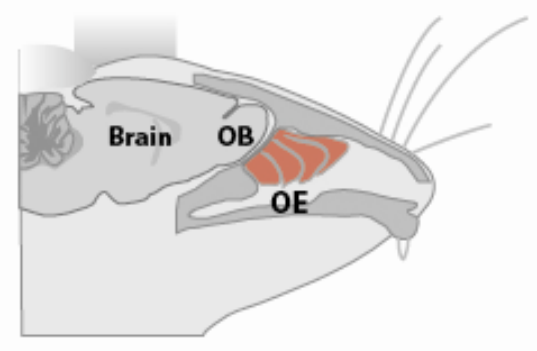

(B)

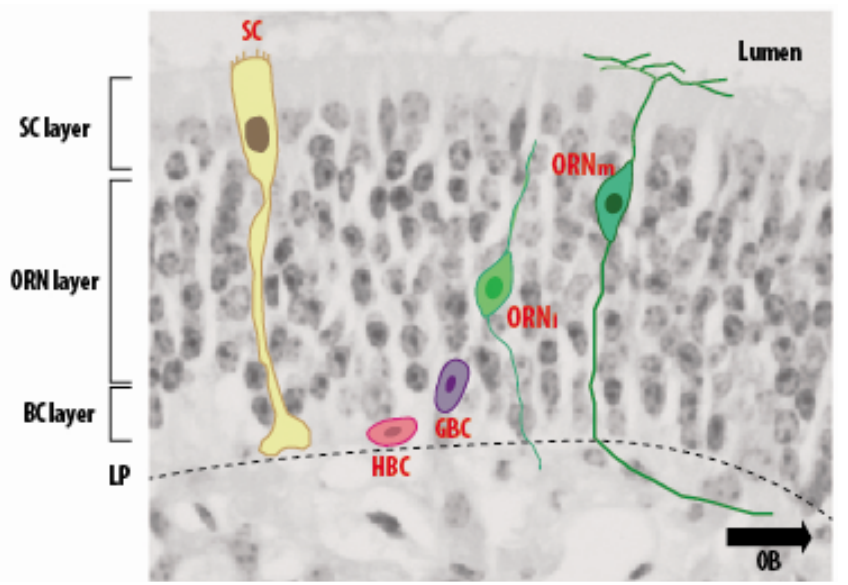

Fig. 1. Structure of olfactory epithelium (OE). (A) Sagittal plane of the rodent nose elucidating the location of the olfactory epithelium (red). (B) The olfactory epithelium is composed of several cell types from apical to basal layers: supporting cells (SCs), immature and mature olfactory receptor neurons (ORNs), and globose and horizontal basal cells (GBCs and HBCs). LP: lamina propria. 


\section{Adult neurogenesis and regeneration in the $\mathrm{OE}$}

The OE retains active processes for supplying new ORNs throughout life; it also has the capacity to regenerate in response to many types of damage. Under normal conditions, ORNs degenerate and die constantly, being replaced by the proliferation and differentiation of basal cells every few days (51). Severing axons by axonal dissection or olfactory bulbectomy (ablation of olfactory bulb) triggers apoptosis in ORNs, and proliferation of basal cells within a few days (52). Complete restoration of the OE takes almost 4 weeks, and new ORNs target their axons and recover their functional synapses in the OB. Upon injury or exposure to chemical toxins such as $\mathrm{MeBr}$ or zinc sulfate, which cause massive degeneration of ORNs, supporting cells and GBCs, the entire OE takes several months to be restored to its prelesion state $(43,53,54)$.

During adult neurogenesis and regeneration, cell proliferation and cell fate determination for differentiation is preceded by developmental interactions among the comprised cells in the OE. The identification of cells involved in adult neurogenesis and regeneration have been studied. GBCs and HBCs have emerged as candidate stem cells of the OE for years. It is considered that GBCs are neuronal progenitors committed to the ORN lineage passing through transit amplifying cells or late immediate neuronal precursors (INPs) in the OE $(13,51$, $55,56)$. However, several studies suggest that they also act as multipotent progenitors to generate all of the other types of the olfactory cells $(15,45,57,58)$. Following mild injury, in which the damage is limited to ORNs (such as olfactory bulbectomy or olfactory nerve transection), GBCs are likely to increase their proliferation and rapidly reconstitute the lost cell types (59). HBCs act like realistic olfactory stem cells with the hallmark of well-characterized adult stem cells, having very slow proliferation under normal regeneration, which is sufficient to maintain the GBC population. After extensive damage, they can give rise to all of the different cell types in the OE by cre-lox lineage tracing studies $(48,49,60,61)$.

In the neuronal lineage of the $\mathrm{OE}, \mathrm{GBCs}$ consisting of early transit-amplifying cells, and INPs which express proneural genes such as Mash1 and Ngn1, are involved in the regular renewal of ORNs after injury (Fig. 2A) (56). INPs give rise to daughter cells that exit the cell cycle and differentiate into immature ORNs, move to the apical region in the intermediate layers $(1,55)$. Differentiation of these cells into mature ORNs involves the expansion of a dendrite and axon at the opposite poles of the neurons. Terminal differentiation of mature ORNs climaxes with establishment of synapses at glomeruli in the olfactory bulb, targeting on a particular region from sensory neurons expressing the same odorant receptor (62-66). In the non-neuronal lineage of the $\mathrm{OE}$, supporting cells are first driven from the basal cells after injury with expression of Hes1, which is known to suppress transcription factor (TF) of proneural genes (Fig. 2B) $(57,67,68)$. Taken together, it suggests that the regeneration of ORNs and other cell types in the $\mathrm{OE}$ may keep pace with the increased loss of these cell population
(A)

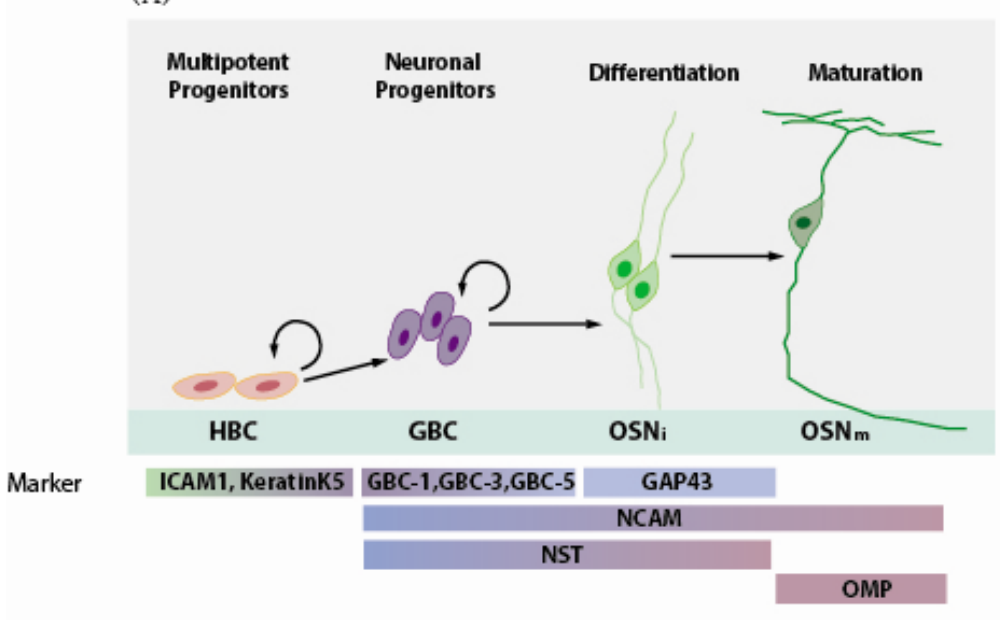

(B)

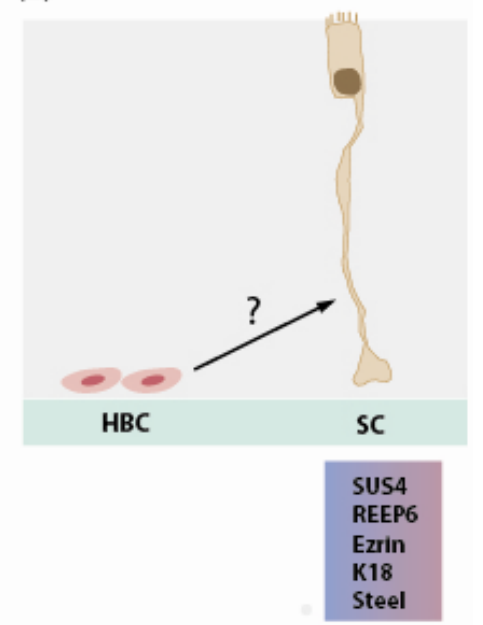

Fig. 2. Process of regeneration in the OE. The OE retains active processes for supplying new ORNs and supporting cells during regeneration. These cell types can be distinguished by several markers. (A) During ongoing ORNs generation, HBCs and act as olfactory stem cells for other cells in the OE. After neuronal cell fate determination of GBCs, they differentiate and maturate into ORNs. (B) In the non-neuronal lineage of the $\mathrm{OE}$, supporting cells are generated from $\mathrm{HBCs}$, but detailed process is under investigation. GBCt: transit amplifying globose basal cell, GBCinp: immediate neuronal precursor globose basal cell, ORNi: immature olfactory receptor neuron, ORNm: mature olfactory receptor neuron, ICAM1: Intercellular Adhesion Molecule 1, GAP43: 43kDa growth associated protein, NCAM: neural cell adhesion molecule, NST: neuron specific tubulin, OMP: olfactory marker protein, SUS4: sucrose synthase 4, Reep6: Receptor Accessory Protein 6, K18: keratin 18 . 
or changes of cell type compositions, accompanied by aging or environmental factors.

\section{Transcriptional network during adult neurogenesis and regeneration in the $\mathrm{OE}$}

The network of transcription factors (TFs) by which adult neurogenesis and regeneration is regulated in the $\mathrm{OE}$ remains unclear. Many have yet to be clearly defined, perhaps because the TF expression patterns that manage the initial development of embryos has been established, but not in adult neurogenesis and regeneration. It has been investigated by up- vs. down- experiments to identify master regulators to generate ORNs and other cell types in the $\mathrm{OE}$ from basal cells, using the regeneration model system. The determination of cell types in the $\mathrm{OE}$ shares some common TF expression patterns that are similar to those expressed at the embryonic or postnatal stages. We will highlight a few master TFs in the adult neurogenesis and regeneration of $\mathrm{OE}$.

Maintenance (Proliferation) of multipotent progenitors: The TFs Sox 2 and Pax 6 are required for maintenance of multipotent progenitor cells in the $\mathrm{OE}$, similar to the other regions of the nervous system. In the embryonic development of $\mathrm{OE}$, they often function together at a very early stage in the nasal placode for initial formation of olfactory sensory epithelium (69). Sox2 (SRY-box containing gene 2) is a member of the Sox family, which contains the high-mobility group (HMG); it is one of the key factors in regulating the embryonic stem cell self-renewal and inducing somatic cells to become pluripotent stem cells (70-72). In the nervous system, Sox is a persistent marker for multipotent progenitor/stem cells isolated from the embryonic
CNS; also, using the Sox2-GFP mouse line, it has been shown that the adult CNS strongly expresses Sox at the region where adult neurogenesis occurs $(71,73)$. Sox2 is expressed in both the basal and apical layers in the $\mathrm{OE}$, corresponding with the location of proliferating cells at a very early developmental stage. Blocking the neuronal lineage in the OE, Sox2 expression expands to most of the cells beyond its initial expression region $(4,69)$. Pax6 (Paired box 6) is a member of paired box family and contains paired domain and partial or complete homeo box domain. It regulates the multipotent progenitor cells in diverse systems, including CNS (74). Studies show that Pax6 is involved in olfactory development, since nose formation failed in the Pax6 mutant animals (75). It is also expressed in adult $\mathrm{OE}$, especially cells of the non-neuronal lineages, including HBCs and supporting cells (76). The involvement of Sox2 and Pax6 in the development of OE was identified from genetic studies, where Sox 2 and Pax 6 were expressed by a variety of cell types in the normal adult and $\mathrm{MeBr}$ lesioned-regenerating OE. Both TFs are expressed in supporting cells, multipotent GBCs, Mash1 + GBCs (commonly committed to the neuronal lineage), and HBCs $(43,76,77)$. Sox2 and Pax6 may play multiple and complex roles in the regulation of olfactory neurogenesis as well as for the maintenance of multipotency (Table 1, Fig. 3).

Recent studies implicated that p63 also has an important role in maintenance of multipoteny in the OE. p63 is a member of the p53 tumor suppressor gene family known to maintain self-renewal or cell survival of stem cells in other stratified epithelia (78, 79). Using p63 null mutation germline, it was confirmed that p63 is required for the generation of HBCs dur-

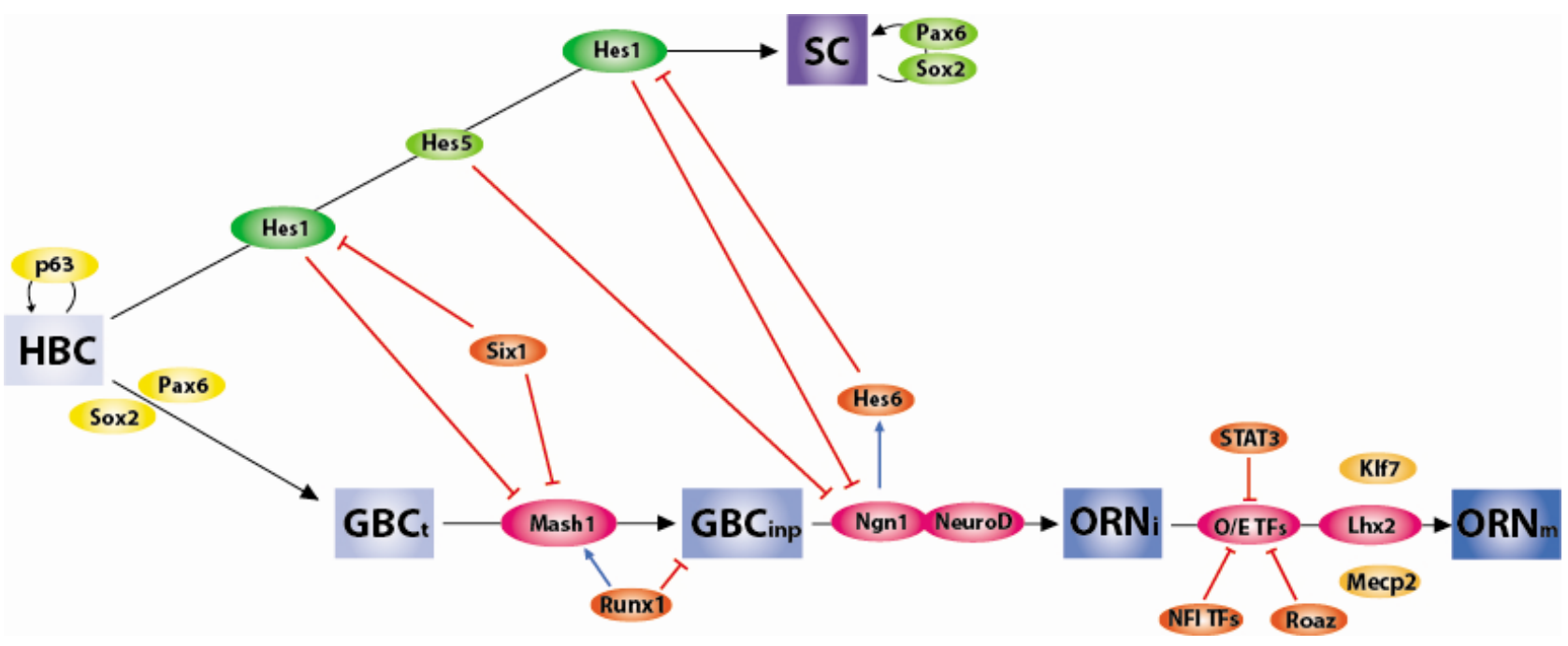

Fig. 3. Scheme of transcriptional regulatory network during regeneration in the OE. Sox2, Pax6 and p63 regulate proliferation and differentiation of multipotent progenitor cells. Two representative bHLH TFs, Mash1 and Hes1 might have role in the determination of cell fate between neuronal and non-neuronal lineages. And their multiple component of the downstream get involved in differentiation and final maturation of each cell fate. $\mathrm{GBC}_{\mathrm{t}}$ : transit amplifying globose basal cell, $\mathrm{GBC}_{\mathrm{inp}}$ : immediate neuronal precursor globose basal cell, ORN immature olfactory receptor neuron, $\mathrm{ORN}_{\mathrm{m}}$ : mature olfactory receptor neuron. 
ing embryogenesis (80). p63 contributes to maintain HBCs self-renewal and is not involved in their differentiation, as $\mathrm{HBC}$ can give rise to differentiated cells of the OE during injury-induced regeneration in the conditional p63 knockout (61). Although the possible interactions among p63, Sox2 and Pax6, which are relevant to multipotency in adult OE have not been clearly defined, Sox 2 and Mash1 seems to be affected by conditional p63 knockout (61) (Table 1, Fig. 3).

The TF regulation of multipotent progenitor cells has led to the proposal that they form a transcriptional regulatory network for keeping their balance between proliferation and differentiation in the adult OE.

Neurogenesis: During regeneration, progenitors undergo several processes to make various cell types which comprise the $\mathrm{OE}$; these include cell fate determination between neuronal and non-neuronal lineages, their differentiation and maturation. In the $\mathrm{OE}$, Mash1 and Hes1 function as a molecular switch that determines the cell fate of the two cell lineages, the ORNs and non-neuronal cells, especially the supporting cells (Fig. 3). Two representative bHLH (basic helix-loop-helix) TFs act as transcriptional activators or repressors to each other, during embryonic neuronal development of OE (68). Targeted knockout animals, overexpression studies, and the changes in spatial or temporal expression of multiple components downstream of Mash1 and Hes1 following injury, emphasize its importance in regulating olfactory epithelial cell fate. These transcriptional regulations that govern embryonic and adult neurogenesis/regeneration overlap each other, but are not identical.

Mash1 (Mammalian Achaete Scute Homolog 1) is a member of the bHLH family; it plays a role in neuronal commitment and differentiation at the selected point in the olfactory system $(13,14,81-83)$. Mash1 is expressed at most layers in the developing $\mathrm{OE}$, especially in transit amplifying progenitor cells, but not in differentiated ORNs $(13,56,84)$. The generation of ORNs is blocked almost completely by depletion of Mash1 during the embryonic stage. Loss of Mash1 results in the fail-

Table 1. Changes of TFs during regeneration in the OE

\begin{tabular}{|c|c|c|c|c|c|c|}
\hline Stage & TFs & Family & Localization & Age & Network & Ref \\
\hline \multirow{3}{*}{$\begin{array}{l}\text { Maintenance of } \\
\text { multipotent } \\
\text { progenitors }\end{array}$} & Sox2 & Sox & Most layers & $\mathrm{E}$ & $(+) \operatorname{Pax} 6$ & $(77)$ \\
\hline & Pax6 & Paired & Most layers & $E, P, A$ & $(+)$ Sox 2 & (77) \\
\hline & P63 & $\begin{array}{c}\text { P53 tumor } \\
\text { suppressor gene }\end{array}$ & B & $\mathrm{P}, \mathrm{A}$ & & (61) \\
\hline \multirow[t]{3}{*}{$\begin{array}{l}\text { Neuronal cell fate } \\
\text { determination }\end{array}$} & Mash1 & bHLH & Most layers & $E, P, A$ & $\begin{array}{c}(-) \text { Hes1 Six1 } \\
(+) \text { Runx1 Wt1 } \\
(\sim) \text { Pax6 Sox2 }\end{array}$ & $(13-15,56,115-118)$ \\
\hline & Six1 & HD-Six & $\mathrm{B}, \mathrm{A}$ & $E, A$ & & $(90.119)$ \\
\hline & Lhx2 & LIM & $B, I$ & $E, A$ & $\begin{array}{c}(+) \text { NeuroD } \\
(\sim) \text { Mash1 Ngn1 }\end{array}$ & $(14,101,120,121)$ \\
\hline \multirow[t]{4}{*}{ ORN differentiation } & Ngn1 & bHLH & B & $\mathrm{E}, \mathrm{A}$ & $\begin{array}{c}(+) \text { Mash1 } \\
(-) \text { Hes1 Hes5 }\end{array}$ & $(13-15)$ \\
\hline & NeuroD & bHLH & B & $E, P, A$ & $(+)$ Ngn1 Runx1 & (112) \\
\hline & Hes6 & bHLH & B & $E, P, A$ & $(+)$ Ngn1 & $(119,122)$ \\
\hline & Runx1 & Runx & B & $\mathrm{E}, \mathrm{P}$ & & (84) \\
\hline \multirow[t]{6}{*}{ ORN maturation } & $\mathrm{O} / \mathrm{E}$ TFs & $\begin{array}{c}\mathrm{O} / \mathrm{E} \\
(\mathrm{Olf} / \mathrm{EBF})\end{array}$ & $B, I$ & $E, P, A$ & $\begin{array}{c}(+) \text { NeuroD } \\
(-) \text { NF I TFs STAT3 Roaz }\end{array}$ & $(14,76,98)(94-96)$ \\
\hline & STAT3 & STAT & $?$ & $\mathrm{P}, \mathrm{A}$ & & (99) \\
\hline & NF I TFs & NF I & Most layers & $E, P$ & & (98) \\
\hline & Roaz & Zn finger & $\mathrm{B}, \mathrm{I}$ & A & & (102) \\
\hline & Меср2 & MBD & Most layers & $E, P, A$ & & (103. 106) \\
\hline & KIf7 & Zn finger & $?$ & $E, P$ & & $(104,105,107)$ \\
\hline \multirow[t]{4}{*}{$\begin{array}{l}\text { Non-neuronal } \\
\text { differentiation }\end{array}$} & Hes1 & bHLH & A & $E, A$ & $\begin{array}{l}(+) \text { Hes5 } \\
(-) \text { Hes6 }\end{array}$ & (14. 108) \\
\hline & Hes5 & $\mathrm{bHLH}$ & B & $E, A$ & $(+)$ Hes1 & (14. 108) \\
\hline & Sox2 & Sox & Most layers & $E, P, A$ & & (77) \\
\hline & Pax6 & Paired & Most layers & $E, P, A$ & & $(77)$ \\
\hline
\end{tabular}

Localization; B: basal, I: intermediate, A: apical, Age; E: embryonic, P: postnatal, A: adult), $(+)$ : promotion, $(-)$ : inhibition, $(\sim)$ : unrelatedness (modified from (116)). 
ure of the sequential expression of Ngn1 (Neurogenin1) and NeuroD, which culminate in the production of ORNs $(4,13$, $62,85,86)$. Thus, Mash1 could be crucial for progression to a neuronal fate at early stage of ORN development (Table 1, Fig. 3).

The effects of Mash1 expression on adult neurogenesis and regeneration has also been studied extensively. In the developing epithelium after olfactory bulbectomy or exposure to MeBr, Mash1 and proneuronal bHLH TFs, Ngn1 and NeuroD are sequentially expressed in the similar expression pattern during embryonic development of the $\mathrm{OE}$. The epistatic relationship and the timing of their expression implicates that Ngn1 and NeuroD act downstream of Mash1, and have features of INPs. Ngn1 and NeuroD are expressed in cells of the GBC layer, and in cells above Mash1+ GBCs. In Ngn1 (Neurogenin1) null mutant $\mathrm{OE}$, multipotent progenitors are generated, but their initial differentiation to ORNs is blocked. NeuroD follows after the Ngn1 expression during terminal-differentiation of ORNs under regeneration $(14,15,77,87-89)$ (Table 1, Fig. 3).

Multiple TFs have been suggested or shown to act along with with Mash1, Ngn1 and NeuroD1 to continue neurogenesis in the OE. Six1, a member of the HD-Six family, seems to regulate the determination of cell fate in the developing $\mathrm{OE}$. Its expression increases simultaneous with the Ngn1 expression after olfactory bulbectomy (88). It was observed that the expression of Mash1 and Hes1 increases in Six $1 \mathrm{KO}$ mice (90). Runx 1, a member of the Runx family, is important in preventing premature differentiation of multipotent neuronal progenitors in the $\mathrm{OE}$, and Runx1 expression was seen to increase after olfactory bulbectomy. The Runx1-deficient mice exhibit a significant decrease in the number of NeuroD + cells, but have an unaltered expression of Mash1 $(84,88)$. Hes6 seems to promote neuronal differentiation in the $\mathrm{OE}$, being downstream of Ngn1, perhaps by suppressing Hes1 (89). These studies reveal that three bHLH TFs and other networking TFs function as the determining factors or differentiation factors, depending on the timing of their expression in neuronal progenitors in the OE (Table 1, Fig. 3).

There are many other TFs which are involved in ORN maturation. In particular, O/E TFs (Olf/EBF TFs) play a key role in the stage that enhances the expression of OMP, Golf, OcNc and, ACIII binding to their promoter regions (91-95). O/E TFs deficient mice fail to format and innervate the synapse with glomerulus in the OE (96). As OMP expression is also detected in the OE/TFs deficient mice, it is believed that other numerous TFs also contribute to ORN maturation and functions (96, 97). Nuclear factor I (NF I) TFs and STAT3 bind to OMP promoter and negatively regulate the expression of genes involved in terminal differentiation $(98,99)$. It is assumed that NF I TFs interfere with O/E TFs, as the mutation of NF I binding sites in the OMP promoter region results in OMP activation by O/E TFs $(98,100)$. Lhx2 (LIM-homeodomain 2) gets involved in the terminal differentiation of ORNs, since Lhx2 con- ditional inactivation in ORNs cannot innervate their target in the olfactory bulb (101). Although Roaz (a rat C2H2 zinc finger protein), Mecp2 (methyl CpG binding protein 2), and Klf7 (Kruppel like TF 7) were detected in the mature ORNs, and their expression changed at the maturation stage after olfactory bulbectomy or embryonic development, the mechanisms which mediate the maturation process remains to be determined (14, 76, 102-107) (Table 1, Fig. 3).

Non-neuronal differentiation: Hes1 (mammalian homolog of Drosophila Hairy and Enhancer of split 1) (108), is a member of the bHLH family, and several studies have shown that Hes1 in particular has important roles in non-neuronal differentiation in the OE (Fig. 3) (109-113). Following Hes1 null mutant mice study, it was found that initially, the Hes 1 functions in restricting a region of proneuronal gene expression at the onset of neurogenesis, and subsequently inhibits the recruitment of neuronal progenitors in the embryonic OE. Mash1 interacts with Hes 1 for these two functions (108). Hes1 is expressed by the supporting cells of apical layers in the normal adult $\mathrm{OE}$ or after olfactory bulbectomy (15). After MeBr treatment, Hes1 is expressed in the basal cells, Hes1 + basal cells are displaced to the apical end as regeneration progresses, and finally differentiates into the supporting cells $(13,108)$. Hes 1 expression seems to mark the commitment to supporting cell fate with suppression of Mash1 in neuronal progenitors. There are also transcriptional interactions between Hes 1 and other TFs to proceed to non-neuronal differentiation. Hes 5 functions as a repressor in neurogenesis synergized with Hes1, as it regulates the expression of Ngn1 exclusively (108, 114). The Hes1 and Mash1 seem to have a reciprocal relationship during regeneration. Mash1 reappears after Hes1 expression, during regeneration following $\mathrm{MeBr}$ lesions. Loss of Mash1 induces the elimination of Hes1 expression, while loss of Hes 1 allows an extension of the Mash1 expression and the production of neurons in the developing $\mathrm{OE}(13,108)$ (Table 1, Fig. 3 ).

These studies reveal that making a choice between ORNs and supporting cells is followed by expression of two types of TFs: transcriptional activators that drive neuronal lineage, including Mash1, Ngn1 and NeuroD, and transcriptional repressors of neuronal differentiation that belong to the Hes group (15). Further insight into the network of these molecular signals which controls the choice between making ORNs vs. non-neuronal cells in the $\mathrm{OE}$, should be gleaned from future studies focusing on the mechanisms and interacting partners.

\section{CONCLUSION}

The past decade has witnessed a decrease in stem cell transplantation for injuries related to the nervous system, and the introduction of new approaches of regenerative medicines. These approaches are now focused on the regulatory mechanisms of ongoing cell replacement which facilitates robust regeneration in the $\mathrm{OE}$, which otherwise do not appear in the retina or cochleae. Numerous TFs are expressed in each cell 
type of $\mathrm{OE}$, along with spatial and temporal differences in the features of the transcriptional regulatory networks that characterize them during regeneration. Deciphering these networks is likely to provide new insights into the regulation of cell identity in the OE. It is also evident that TFs are powerful modulators of development as they can induce the transition between different cell states. There are many aspects of the regulation of $\mathrm{OE}$ regeneration that still remain unknown. But one can imagine a scheme in which these pathways could be targeted by gene therapy to maintain multipotent progenitors, or initiate a process of regulated reprogramming for facilitating neurogenesis in regions of the adult nervous system where regeneration is limited or absent. Indeed, viral expression of Atoh1 has already been shown to regenerate some hair cells from damaged cochlea in the mammalian inner ear (115). Understanding the TF mechanisms regulating adult neurogenesis and regeneration will enable the development for cell replacement therapy, using either endogenous progenitors or reprogramming cells from different sources, and possibly create novel ones.

\section{ACKNOWLEDGEMENTS}

Authors are grateful to Mr. Samhwan Kim for his art works. This work was supported by the Ministry of Science, ICT and Future Planning \& DGIST (15-BD-0402, DGIST Convergence Science Center) to CM.

\section{REFERENCES}

1. Graziadei GA and Graziadei PP (1979) Neurogenesis and neuron regeneration in the olfactory system of mammals. II. Degeneration and reconstitution of the olfactory sensory neurons after axotomy. J Neurocytol 8, 197-213

2. Graziadei PP, Levine RR and Monti Graziadei GA (1979) Plasticity of connections of the olfactory sensory neuron: regeneration into the forebrain following bulbectomy in the neonatal mouse. Neuroscience 4, 713-727

3. Mackay-Sim A and Kittel PW (1991) On the Life Span of Olfactory Receptor Neurons. Eur J Neurosci 3, 209-215

4. Smart IH (1971) Location and orientation of mitotic figures in the developing mouse olfactory epithelium. J Anat 109, 243-251

5. Bodian D and Howe HA (1941) Experimental studies on intraneural spread of poliomyelitis virus. Bulletin of the Johns Hopkins Hospital 68, 248-267

6. Rawson NE, Gomez G, Cowart B and Restrepo D (1998) The use of olfactory receptor neurons (ORNs) from biopsies to study changes in aging and neurodegenerative diseases. Ann N Y Acad Sci 855, 701-707

7. Lane AP, Gomez G, Dankulich T, Wang H, Bolger WE and Rawson NE (2002) The superior turbinate as a source of functional human olfactory receptor neurons. Laryngoscope 112, 1183-1189

8. Rawson NE and Gomez G (2002) Cell and molecular biology of human olfaction. Microsc Res Tech 58, 142-151
9. Gross CG (2000) Neurogenesis in the adult brain: death of a dogma. Nat Rev Neurosci 1, 67-73

10. Kempermann G and Gage FH (1999) New nerve cells for the adult brain. Sci Am 280, 48-53

11. Lie DC, Song H, Colamarino SA, Ming GL and Gage FH (2004) Neurogenesis in the adult brain: new strategies for central nervous system diseases. Annu Rev Pharmacol Toxicol 44, 399-421

12. Bailey BJ and Barton S (1975) Olfactory neuroblastoma. Management and prognosis. Arch Otolaryngol 101, 1-5

13. Cau E, Gradwohl G, Fode C and Guillemot F (1997) Mash1 activates a cascade of bHLH regulators in olfactory neuron progenitors. Development 124, 1611-1621

14. Cau E, Casarosa S and Guillemot F (2002) Mash1 and Ngn1 control distinct steps of determination and differentiation in the olfactory sensory neuron lineage. Development 129, 1871-1880

15. Manglapus GL, Youngentob SL and Schwob JE (2004) Expression patterns of basic helix-loop-helix transcription factors define subsets of olfactory progenitor cells. J Comp Neurol 479, 216-233

16. Eggan K, Baldwin K, Tackett M et al (2004) Mice cloned from olfactory sensory neurons. Nature 428, 44-49

17. Li J, Ishii T, Feinstein $P$ and Mombaerts $P(2004)$ Odorant receptor gene choice is reset by nuclear transfer from mouse olfactory sensory neurons. Nature 428, 393-399

18. Lindvall $\mathrm{O}$ and Bjorklund A (2004) Cell replacement therapy: helping the brain to repair itself. NeuroRx 1, 379-381

19. Rossi F and Cattaneo E (2002) Opinion: neural stem cell therapy for neurological diseases: dreams and reality. Nat Rev Neurosci 3, 401-409

20. Graziadei PPC and Montigraziadei GA (1979) Neurogenesis and Neuron Regeneration in the Olfactory System of Mammals .1. Morphological Aspects of Differentiation and Structural Organization of the Olfactory Sensory Neurons. J Neurocytol 8, 1-18

21. Moulton DG (1967) Olfaction in mammals. Am Zool 7, 421-429

22. Moulton DG and Beidler LM (1967) Structure and function in the peripheral olfactory system. Physiol Rev 47, $1-52$

23. Doty RL (2001) Olfaction. Annu Rev Psychol 52, 423-452

24. Menco BP and Farbman Al (1992) Ultrastructural evidence for multiple mucous domains in frog olfactory epithelium. Cell Tissue Res 270, 47-56

25. Farbman Al and Buchholz JA (1992) Growth of olfactory epithelial tissue in vitro: lectin staining of axons. Microsc Res Tech 23, 173-180

26. Kaupp UB (2010) Olfactory signalling in vertebrates and insects: differences and commonalities. Nat Rev Neurosci $11,188-200$

27. Graziadei PP and Metcalf JF (1971) Autoradiographic and ultrastructural observations on the frog's olfactory mucosa. Z Zellforsch Mikrosk Anat 116, 305-318

28. Graziadei PP (1973) Cell dynamics in the olfactory mucosa. Tissue Cell 5, 113-131

29. Graziadei PP and DeHan RS (1973) Neuronal regeneration in frog olfactory system. J Cell Biol 59, 525-530

30. Hunter DD, Caggiano M and Kauer JS (1994) Lineage 
analysis of the olfactory epithelium using a replication-incompetent retrovirus. Chem Senses 19, 683-693

31. Roskams AJ, Cai X and Ronnett GV (1998) Expression of neuron-specific beta-III tubulin during olfactory neurogenesis in the embryonic and adult rat. Neuroscience 83, 191-200

32. Farbman Al and Margolis FL (1980) Olfactory marker protein during ontogeny: immunohistochemical localization. Dev Biol 74, 205-215

33. Hirsch JD and Margolis FL (1980) Influence of unilateral olfactory bulbectomy on opiate and other binding sites in the contralateral bulb. Brain Res 199, 39-47

34. Getchell TV, Zielinski B and Getchell ML (1985) Pyrazine-Mediated Neural and Secretory Activity in the Olfactory Mucosa of the Salamander. Chemical Senses 10, 398-399

35. Getchell TV (1986) Functional-Properties of Vertebrate Olfactory Receptor Neurons. Physiol Rev 66, 772-818

36. Nomura T, Takahashi S and Ushiki T (2004) Cytoarchitecture of the normal rat olfactory epithelium: light and scanning electron microscopic studies. Arch Histol Cytol $67,159-170$

37. Gu J, Zhang QY, Genter MB et al (1998) Purification and characterization of heterologously expressed mouse CYP2A5 and CYP2G1: role in metabolic activation of acetaminophen and 2,6-dichlorobenzonitrile in mouse olfactory mucosal microsomes. J Pharmacol Exp Ther 285, 1287-1295

38. Whitby-Logan GK, Weech M and Walters E (2004) Zonal expression and activity of glutathione S-transferase enzymes in the mouse olfactory mucosa. Brain Res 995, 151-157

39. Ling G, Gu J, Genter MB, Zhuo X and Ding X (2004) Regulation of cytochrome $\mathrm{P} 450$ gene expression in the olfactory mucosa. Chem Biol Interact 147, 247-258

40. Ding XX and Coon MJ (1988) Purification and characterization of two unique forms of cytochrome P-450 from rabbit nasal microsomes. Biochemistry 27, 8330-8337

41. Chen Y, Getchell ML, Ding X and Getchell TV (1992) Immunolocalization of two cytochrome P450 isozymes in rat nasal chemosensory tissue. Neuroreport 3, 749-752

42. Weiler E and Farbman Al (1998) Supporting cell proliferation in the olfactory epithelium decreases postnatally. Glia 22, 315-328

43. Schwob JE, Youngentob SL and Mezza RC (1995) Reconstitution of the rat olfactory epithelium after methyl bromide-induced lesion. J Comp Neurol 359, 15-37

44. Goldstein BJ and Schwob JE (1996) Analysis of the globose basal cell compartment in rat olfactory epithelium using GBC-1, a new monoclonal antibody against globose basal cells. J Neurosci 16, 4005-4016

45. Huard JM, Youngentob SL, Goldstein BJ, Luskin MB and Schwob JE (1998) Adult olfactory epithelium contains multipotent progenitors that give rise to neurons and non-neural cells. J Comp Neurol 400, 469-486

46. Huard JM and Schwob JE (1995) Cell cycle of globose basal cells in rat olfactory epithelium. Dev Dyn 203, 17-26

47. Carter LA, MacDonald JL and Roskams AJ (2004) Olfactory horizontal basal cells demonstrate a conserved multi- potent progenitor phenotype. J Neurosci 24, 5670-5683

48. Leung CT, Coulombe PA and Reed RR (2007) Contribution of olfactory neural stem cells to tissue maintenance and regeneration. Nat Neurosci 10, 720-726

49. Iwai N, Zhou Z, Roop DR and Behringer RR (2008) Horizontal basal cells are multipotent progenitors in normal and injured adult olfactory epithelium. Stem Cells 26, 1298-1306

50. Beites CL, Kawauchi S, Crocker CE and Calof AL (2005) Identification and molecular regulation of neural stem cells in the olfactory epithelium. Exp Cell Res 306, 309316

51. Caggiano M, Kauer JS and Hunter DD (1994) Globose basal cells are neuronal progenitors in the olfactory epithelium: a lineage analysis using a replication-incompetent retrovirus. Neuron 13, 339-352

52. Cowan CM and Roskams AJ (2002) Apoptosis in the mature and developing olfactory neuroepithelium. Microsc Res Tech 58, 204-215

53. Hurtt ME, Thomas DA, Working PK, Monticello TM and Morgan KT (1988) Degeneration and regeneration of the olfactory epithelium following inhalation exposure to methyl bromide: pathology, cell kinetics, and olfactory function. Toxicol Appl Pharmacol 94, 311-328

54. Cancalon P (1982) Degeneration and regeneration of olfactory cells induced by $\mathrm{ZnSO} 4$ and other chemicals. Tissue Cell 14, 717-733

55. Calof AL and Chikaraishi DM (1989) Analysis of neurogenesis in a mammalian neuroepithelium: proliferation and differentiation of an olfactory neuron precursor in vitro. Neuron 3, 115-127

56. Gordon MK, Mumm JS, Davis RA, Holcomb JD and Calof AL (1995) Dynamics of MASH1 expression in vitro and in vivo suggest a non-stem cell site of MASH1 action in the olfactory receptor neuron lineage. Mol Cell Neurosci 6, 363-379

57. Chen X, Fang H and Schwob JE (2004) Multipotency of purified, transplanted globose basal cells in olfactory epithelium. J Comp Neurol 469, 457-474

58. Gokoffski KK, Wu HH, Beites CL et al (2011) Activin and GDF11 collaborate in feedback control of neuroepithelial stem cell proliferation and fate. Development $138,4131-4142$

59. Carr VM and Farbman Al (1992) Ablation of the olfactory bulb up-regulates the rate of neurogenesis and induces precocious cell death in olfactory epithelium. Exp Neurol 115, 55-59

60. Li L and Clevers H (2010) Coexistence of quiescent and active adult stem cells in mammals. Science $327,542-545$

61. Fletcher RB, Prasol MS, Estrada J et al (2011) p63 regulates olfactory stem cell self-renewal and differentiation. Neuron 72, 748-759

62. Cuschieri A and Bannister LH (1975) The development of the olfactory mucosa in the mouse: electron microscopy. J Anat 119, 471-498

63. Marcucci F, Zou DJ and Firestein S (2009) Sequential onset of presynaptic molecules during olfactory sensory neuron maturation. J Comp Neurol 516, 187-198

64. Mombaerts P, Wang F, Dulac C et al (1996) Visualizing an olfactory sensory map. Cell $87,675-686$ 
65. Schwarzenbacher K, Fleischer J and Breer H (2005) Formation and maturation of olfactory cilia monitored by odorant receptor-specific antibodies. Histochem Cell Biol 123, 419-428

66. Shetty RS, Bose SC, Nickell MD et al (2005) Transcriptional changes during neuronal death and replacement in the olfactory epithelium. Mol Cell Neurosci 30, 583600

67. Goldstein BJ, Fang H, Youngentob SL and Schwob JE (1998) Transplantation of multipotent progenitors from the adult olfactory epithelium. Neuroreport 9, 1611-1617

68. Davis RL and Turner DL (2001) Vertebrate hairy and Enhancer of split related proteins: transcriptional repressors regulating cellular differentiation and embryonic patterning. Oncogene 20, 8342-8357

69. Donner AL, Episkopou V and Maas RL (2007) Sox2 and Pou2f1 interact to control lens and olfactory placode development. Dev Biol 303, 784-799

70. Pevny LH and Lovell-Badge R (1997) Sox genes find their feet. Curr Opin Genet Dev 7, 338-344

71. Pevny L and Placzek M (2005) SOX genes and neural progenitor identity. Curr Opin Neurobiol 15, 7-13

72. Takahashi K and Yamanaka S (2006) Induction of pluripotent stem cells from mouse embryonic and adult fibroblast cultures by defined factors. Cell 126, 663-676

73. Brazel CY, Limke TL, Osborne JK et al (2005) Sox2 expression defines a heterogeneous population of neurosphere-forming cells in the adult murine brain. Aging Cell 4, 197-207

74. Walther C and Gruss P (1991) Pax-6, a murine paired box gene, is expressed in the developing CNS. Development 113, 1435-1449

75. Collinson JM, Quinn JC, Hill RE and West JD (2003) The roles of Pax6 in the cornea, retina, and olfactory epithelium of the developing mouse embryo. Dev Biol 255, 303-312

76. Davis JA and Reed RR (1996) Role of Olf-1 and Pax-6 transcription factors in neurodevelopment. J Neurosci $16,5082-5094$

77. Guo Z, Packard A, Krolewski RC, Harris MT, Manglapus GL and Schwob JE (2010) Expression of pax6 and sox2 in adult olfactory epithelium. J Comp Neurol 518, 4395-4418

78. Osada M, Ohba M, Kawahara C et al (1998) Cloning and functional analysis of human p51, which structurally and functionally resembles p53. Nat Med 4, 839-843

79. Yang A, Kaghad M, Wang Y et al (1998) p63, a p53 homolog at 3q27-29, encodes multiple products with transactivating, death-inducing, and dominant-negative activities. Mol Cell 2, 305-316

80. Packard A, Schnittke N, Romano RA, Sinha S and Schwob JE (2011) Delta Np63 Regulates Stem Cell Dynamics in the Mammalian Olfactory Epithelium. J Neurosci 31, 8748-8759

81. Ball DW, Azzoli CG, Baylin SB et al (1993) Identification of a human achaete-scute homolog highly expressed in neuroendocrine tumors. Proc Natl Acad Sci U S A 90, 5648-5652

82. Jasoni CL, Walker MB, Morris MD and Reh TA (1994) A chicken achaete-scute homolog (CASH-1) is expressed in a temporally and spatially discrete manner in the developing nervous system. Development 120, 769-783

83. Nelson BR, Hartman BH, Ray CA, Hayashi T, BerminghamMcDonogh $\mathrm{O}$ and Reh TA (2009) Acheate-scute like 1 (Ascl1) is required for normal delta-like (DII) gene expression and notch signaling during retinal development. Dev Dyn 238, 2163-2178

84. Theriault FM, Nuthall HN, Dong Z et al (2005) Role for Runx 1 in the proliferation and neuronal differentiation of selected progenitor cells in the mammalian nervous system. J Neurosci 25, 2050-2061

85. Noda M and Harada Y (1981) Development of Olfactory Epithelium in the Mouse - Scanning Electron-Microscopy. Biomedical Research-Tokyo 2, 449-454

86. Holbrook EH, Szumowski KE and Schwob JE (1995) An immunochemical, ultrastructural, and developmental characterization of the horizontal basal cells of rat olfactory epithelium. J Comp Neurol 363, 129-146

87. Nibu K, Li G, Zhang X et al (1999) Olfactory neuron-specific expression of NeuroD in mouse and human nasal mucosa. Cell Tissue Res 298, 405-414

88. Heron PM, Stromberg AJ, Breheny P and McClintock TS (2013) Molecular events in the cell types of the olfactory epithelium during adult neurogenesis. Mol Brain 6, 49

89. Suzuki J, Yoshizaki K, Kobayashi T and Osumi N (2013) Neural crest-derived horizontal basal cells as tissue stem cells in the adult olfactory epithelium. Neurosci Res 75, 112-120

90. Ikeda K, Kageyama R, Suzuki Y and Kawakami K (2010) Six1 is indispensable for production of functional progenitor cells during olfactory epithelial development. Int J Dev Biol 54, 1453-1464

91. Malgaretti N, Pozzoli O, Bosetti A et al (1997) Mmot1, a new helix-loop-helix transcription factor gene displaying a sharp expression boundary in the embryonic mouse brain. J Biol Chem 272, 17632-17639

92. Kudrycki K, Stein-lzsak C, Behn C, Grillo M, Akeson R and Margolis FL (1993) Olf-1-binding site: characterization of an olfactory neuron-specific promoter motif. Mol Cell Biol 13, 3002-3014

93. Wang MM, Tsai RY, Schrader KA and Reed RR (1993) Genes encoding components of the olfactory signal transduction cascade contain a DNA binding site that may direct neuronal expression. Mol Cell Biol 13, 58055813

94. Wang SS, Tsai RY and Reed RR (1997) The characterization of the Olf-1/EBF-like HLH transcription factor family: implications in olfactory gene regulation and neuronal development. J Neurosci 17, 4149-4158

95. Wang SS, Betz AG and Reed RR (2002) Cloning of a novel Olf-1/EBF-like gene, O/E-4, by degenerate oligo-based direct selection. Mol Cell Neurosci 20, 404-414

96. Wang SS, Lewcock JW, Feinstein P, Mombaerts P and Reed RR (2004) Genetic disruptions of O/E2 and O/E3 genes reveal involvement in olfactory receptor neuron projection. Development 131, 1377-1388

97. Lin $\mathrm{H}$ and Grosschedl $\mathrm{R}$ (1995) Failure of B-cell differentiation in mice lacking the transcription factor EBF. Nature 376, 263-267

98. Behrens M, Venkatraman G, Gronostajski RM, Reed RR 
and Margolis FL (2000) NFI in the development of the olfactory neuroepithelium and the regulation of olfactory marker protein gene expression. Eur J Neurosci 12, 1372-1384

99. Moon C, Yoo JY, Matarazzo V, Sung YK, Kim EJ and Ronnett GV (2002) Leukemia inhibitory factor inhibits neuronal terminal differentiation through STAT3 activation. Proc Natl Acad Sci U S A 99, 9015-9020

100. Baumeister H, Gronostajski RM, Lyons GE and Margolis FL (1999) Identification of NFI-binding sites and cloning of NFI-cDNAs suggest a regulatory role for NFI transcription factors in olfactory neuron gene expression. Brain Res Mol Brain Res 72, 65-79

101. Berghard A, Hagglund AC, Bohm S and Carlsson L (2012) Lhx2-dependent specification of olfactory sensory neurons is required for successful integration of olfactory, vomeronasal, and GnRH neurons. FASEB J 26, 3464-3472

102. Tsai RY and Reed RR (1997) Cloning and functional characterization of Roaz, a zinc finger protein that interacts with $\mathrm{O} / \mathrm{E}-1$ to regulate gene expression: implications for olfactory neuronal development. J Neurosci 17, 4159-4169

103. Cohen DR, Matarazzo V, Palmer AM et al (2003) Expression of MeCP2 in olfactory receptor neurons is developmentally regulated and occurs before synaptogenesis. Mol Cell Neurosci 22, 417-429

104. Laub F, Aldabe R, Friedrich V, Ohnishi S, Yoshida T and Ramirez F (2001) Developmental expression of mouse Kruppel-like transcription factor KLF7 suggests a potential role in neurogenesis. Dev Biol 233, 305-318

105. Laub F, Lei L, Sumiyoshi $\mathrm{H}$ et al (2005) Transcription factor KLF7 is important for neuronal morphogenesis in selected regions of the nervous system. Mol Cell Biol 25, 5699-5711

106. Matarazzo V, Cohen D, Palmer AM et al (2004) The transcriptional repressor Mecp2 regulates terminal neuronal differentiation. Mol Cell Neurosci 27, 44-58

107. Kajimura D, Dragomir C, Ramirez F and Laub F (2007) Identification of genes regulated by transcription factor KLF7 in differentiating olfactory sensory neurons. Gene $388,34-42$

108. Cau E, Gradwohl G, Casarosa S, Kageyama R and Guillemot $F$ (2000) Hes genes regulate sequential stages of neurogenesis in the olfactory epithelium. Development 127, 2323-2332

109. Ishibashi M, Moriyoshi K, Sasai Y, Shiota K, Nakanishi S and Kageyama R (1994) Persistent Expression of HelixLoop-Helix Factor Hes-1 Prevents Mammalian Neural Differentiation in the Central-Nervous-System. EMBO J $13,1799-1805$

110. Ishibashi M, Ang SL, Shiota K, Nakanishi S, Kageyama R and Guillemot F (1995) Targeted disruption of mammalian hairy and Enhancer of split homolog-1 (HES-1) leads to up-regulation of neural helix-loop-helix factors, pre- mature neurogenesis, and severe neural tube defects. Genes Dev 9, 3136-3148

111. Kume H, Maruyama K, Tomita T, Iwatsubo T, Saido TC and Obata K (1996) Molecular cloning of a novel basic helix-loop-helix protein from the rat brain. Biochem Biophys Res Commun 219, 526-530

112. Kageyama R and Ohtsuka T (1999) The Notch-Hes pathway in mammalian neural development. Cell Res 9, 179-188

113. Matsue $M$, Kageyama R, Denhardt DT and Noda $M$ (1997) Helix-loop-helix-type transcription factor (HES-1) is expressed in osteoblastic cells, suppressed by $1,25(\mathrm{OH}) 2$ vitamin D3, and modulates $1,25(\mathrm{OH}) 2$ vitamin D3 enhancement of osteopontin gene expression. Bone 20, 329-334

114. Akazawa C, Sasai $Y$, Nakanishi $S$ and Kageyama $R$ (1992) Molecular Characterization of a Rat Negative Regulator with a Basic Helix-Loop-Helix Structure Predominantly Expressed in the Developing Nervous-System. J Biol Chem 267, 21879-21885

115. Kraft S, Hsu C, Brough DE and Staecker H (2013) Atoh1 induces auditory hair cell recovery in mice after ototoxic injury. Laryngoscope 123, 992-999

116. Nicolay DJ, Doucette JR and Nazarali AJ (2006) Transcriptional regulation of neurogenesis in the olfactory epithelium. Cell Mol Neurobiol 26, 803-821

117. Guillemot $F$ and Joyner AL (1993) Dynamic expression of the murine Achaete-Scute homologue Mash-1 in the developing nervous system. Mech Dev 42, 171-185

118. Murray RC, Navi D, Fesenko J, Lander AD and Calof AL (2003) Widespread defects in the primary olfactory pathway caused by loss of Mash1 function. J Neurosci 23, 1769-1780

119. Saito T, Lo L, Anderson DJ and Mikoshiba K (1996) Identification of novel paired homeodomain protein related to C. elegans unc-4 as a potential downstream target of MASH1. Dev Biol 180, 143-155

120. Krolewski RC, Packard A, Jang W, Wildner $\mathrm{H}$ and Schwob JE (2012) Ascl1 (Mash1) knockout perturbs differentiation of nonneuronal cells in olfactory epithelium. PLoS One 7, e51737

121. Tietjen I, Rihel JM, Cao Y, Koentges G, Zakhary L and Dulac C (2003) Single-cell transcriptional analysis of neuronal progenitors. Neuron 38, 161-175

122. Hirota J and Mombaerts P (2004) The LIM-homeodomain protein Lhx2 is required for complete development of mouse olfactory sensory neurons. Proc Natl Acad Sci U S A 101, 8751-8755

123. Kolterud A, Alenius M, Carlsson L and Bohm S (2004) The Lim homeobox gene Lhx2 is required for olfactory sensory neuron identity. Development 131, 5319-5326

124. Suzuki Y, Mizoguchi I, Nishiyama H, Takeda $M$ and Obara N (2003) Expression of Hes6 and NeuroD in the olfactory epithelium, vomeronasal organ and non-sensory patches. Chem Senses 28, 197-205 